Journal of Small Business and Enterprise Development, 200815 (2) 259-273

\title{
Role typologies for enterprising education: the professional artisan?
}

\section{Alistair R. Anderson and Sarah L. Jack}

\author{
Alistair R. Anderson \\ Professor and Director of the Charles P Skene Centre for Entrepreneurship \\ Aberdeen Business School \\ Robert Gordon University \\ Kaim House \\ Garthdee \\ Aberdeen \\ AB $247 \mathrm{QE}$ \\ Tel: +1224263883 \\ Email: a.r.anderson@rgu.ac.uk
}

Sarah L. Jack

Senior Lecturer in Entrepreneurship

Institute for Entrepreneurship and Enterprise Development

Lancaster University Management School

Lancaster

LA1 4YX

Tel: +1524 593540

Email: s.l.jack@lancaster.ac.uk

\section{Role typologies for enterprising education: the professional artisan?}

\begin{abstract}
Purpose of paper

To examine how the context, approach and teaching techniques used for entrepreneurship education need to reflect the different roles that encompass enterprise.

Design

We analyse and reflect upon what attributes, qualities, skills and knowledge are required for the different roles involved in entrepreneurship.

Findings

From our analysis we identify role typologies and argue that teaching entrepreneurship needs to produce a combination of the creative talents of the artist, the skills and ability of the artisan, yet include the applied knowledge of the technician with the know-what of the
\end{abstract}


professional. We then present some examples of pedagogies in entrepreneurship that might be used to develop the skills required for these roles.

Implications

We demonstrate why the teaching of entrepreneurship requires a combination of theory and practice.

Originality

A different approach to understanding entrepreneurial pedagogy may be useful for educators and student

Key words: entrepreneur; enterprise education; teaching entrepreneurship; entrepreneurial pedagogy 


\section{Role typologies for enterprising education: the professional artisan?}

\section{Introduction}

The nature of entrepreneurship, its complexity, variability and contingency, makes it a difficult topic to teach. Yet when we consider the priority that society now places on enterprise, we must recognise the key role that universities have to play in shaping attitudes, supplying knowledge and generally enabling our students as enterprising customers and endowing them as entrepreneurial products. Thus to capture, use and develop the innate abilities of the students, those who should represent the future as the most intelligent stratum of our society, is a major academic challenge. In this paper we argue that entrepreneurial practices combine a variety of roles each demanding different skills, knowledge and capabilities. Accordingly the content, approach and teaching techniques we use need to reflect these different aspects. Consequently the pedagogies required to teach entrepreneurship effectively present a need for a demanding but comprehensive repertoire. Furthermore, we have a particular issue in higher education, in that many training organisations seem very capable of delivering the functional skills needed to start and run a modest small business, so what added value can university level entrepreneurship address?

We begin by exploring the nature of entrepreneurship, which is no easy task, given the variety of ways of being entrepreneurial and the number of ways that entrepreneurship is understood. Moreover, the different demands placed upon entrepreneurial education; those of our students and those that society writ large expects of the heroic entrepreneur, are likely to be very different. We then try to analyse what attributes, qualities, skills and knowledge this requires. Entrepreneurship itself seems to be more about practice, yet a focus on 'doing' may neglect key elements of aspects such as opportunity recognition and assessments of viability 
which can be theoretically informed. But the characteristics of our students, their limited life and business experience, combine with the general problem that all embryonic entrepreneurs seem limited by their own corridors of experience, need to be juxtaposed with their enthusiasm and optimistic outlook. Our analysis of these issues leads us to argue that teaching entrepreneurship needs to produce a combination of the creative talents of the artist, the skills and ability of the artisan, yet include the applied knowledge of the technician with the know-what of the professional.

This presents our problematic, how can we address these different requirements, what needs to be done and how can we do it? This leads us to consider what tools we have in our pedagogic tool kit then examine how these can be best employed. ${ }^{1}$ We consider how lectures, seminars, tutorials, guest speakers and even role playing can work by learning by doing; learning by example; learning from theory to develop deep learning to produce the qualities, attributes and knowledge that we see as important. Finally we consider how well we are doing and what gaps may exist and how we might address them.

\section{The Demand for Entrepreneurship Education}

Although Gartner and Shane (1995) noted that rates of entrepreneurship are at their highest for 100 years, the demand for entrepreneurship and entrepreneurship education appears to be growing. Indeed, Katz (2003: 297) comments that "in the $21^{\text {st }}$ century, entrepreneurship education will become a worldwide product with multiple national and niche competitors competing for intellectual mindshare, students and trainees". Such growth is perhaps not to surprising when we think about the perceived benefits of entrepreneurship. As Heinonen and Poikkijoki (2006) explain, the attributes of entrepreneurship; an innovative approach to

\footnotetext{
${ }^{1}$ This paper draws on material first presented as a working paper, Anderson and Jack (1999). However we have expanded and brought up to date many of the ideas in the light of our experiences and expanding knowledge.
} 
problem solving, high readiness for change, self-confidence and creativity are necessary for economic development. Thus entrepreneurship seems to uniquely offer a solution to problems associated with the increased pace and turbulence of social and economic change. New businesses with new products, new services or simply better products or services, appear to have the flexibility and adaptability to incorporate and adapt change (Galloway et al, 2005). Moreover, new businesses provide the most effective and efficient mechanism for producing and embedding change by acting as test beds of innovation. In the evolutionary conditions of a rapidly evolving socio-economic environment, where there is a large number of new firms each testing, trying out and adapting the suitability of environmental fit of their new products, the survivors, those most fit and most suited, those most able to adapt, will survive and prosper (Delmar and Shane, 2004). Those unfit, whose products don't fit, or those who are unable to adapt, will wither and die. Although catastrophic in personal terms, in evolutionary terms, the mechanics of selection are a socially cheap and economically efficient method for embedding and applying successful innovation.

Henry et al $(2005 ; 100)$ see four types of change which have impacted on the demand for entrepreneurship education. Globally, they note how the reduction of trade barriers together with the advancements in telecommunications, technology and transportation all combine to provide more opportunities, as well as more uncertainty in the world. Then at the societal level, privatisation, deregulation, new forms of governance, mounting environmental concerns and the growing recognition of the rights of minority groups all present society with greater complexity and uncertainty. Whilst at the organisational level, decentralisation, downsizing, re-engineering, strategic alliances, mergers and the growing demand for flexibility in the workforce, all contribute to an uncertain climate. Finally, at the individual level, the individual is now faced with a wider variety of employment options, the probability 
of ending up with a portfolio of jobs (Galloway et al, 2005). Students in particular are thought to seek education that equips them with transferable skills (Cooper et al, 2004). Matley (2006) concludes that the range of socio-economic and politically expedient reasons has caused entrepreneurship education to rise to the top of the political agenda and it is currently a high priority item of policy throughout the industrially developed and developing world. Moreover, Matlay (2001) also suggests that in recent years it has become fashionable to view entrepreneurship and entrepreneurship education as the panacea for stagnating or declining economic activity in both developed and developing countries. Consequently Henry et al (2005) maintain that the need for entrepreneurship education has never been greater, and the opportunities have never been so abundant.

This demand began in 1980s and 1990s when we saw an unprecedented growth in the demand for enterprise education which was matched by a corresponding growth in the number of courses offered by both academic institutions and by enterprise agencies of one sort or another, (Curran 1986). This situation has not changed and the number of courses offered at both undergraduate and postgraduate level continues to flourish, with phenomenal growth being experienced both in and outside the US (Collins, Smith and Hannon, 2006; Katz, 2003; Finkle and Deeds, 2001; Jones and English, 2004). Alongside this growth we have experienced a rise in the number of publications related to entrepreneurship, small business and education, with trade and textbooks particularly being estimated to double every year (Katz, 2003). However, questions arise over the form that entrepreneurship education might take in the future (Katz, 2003).

Hannon (2006) noted the number of enterprise initiatives in the UK and concluded that entrepreneurship education is now established as part of higher education. He suggests that 
by 2006 most UK universities will be offering a course or educational experience related to enterprise or entrepreneurship. This is certainly the case in Scotland, where all universities currently have some sort of entrepreneurship offering. So as Kirby (2003) suggests, business and entrepreneurial development is now one of the four strategic goals of British universities. Adcroft et al (2005) provide a different account for the increased provision of entrepreneurship education. They propose that three broad intellectual and policy trends explain this well. First the link between education levels and economic prosperity; second the increasing emphasis on management as a cause of organisational success and finally, the desire of the public sector to remake itself in the image of the private sector. Galloway et al (2005) rather more succinctly suggest that higher education has an important role because universities provide access to knowledge based resources. Young (1997) suggests that there are two sets of reasons why students may want to study entrepreneurship. First, the student may plan to start up their own business; secondly, they may wish to acquire knowledge which will be helpful in their careers in larger organisations. Tan et al (1995), even propose that some students may be attracted to enterprise learning as an insurance against an economic downturn. Furthermore, as Timmons (1994:vii) notes in the USA, about one in eight is self employed and the vast majority of the two million "millionaires" in the US have accumulated their wealth through entrepreneurial acts of self employment. Thus it comes as little surprise to find that the Gallup report (1994) claims a demand for entrepreneurship education from students. Some $85 \%$ of their respondents indicated a desire to learn more about entrepreneurship. This is confirmed by the cross cultural study by Weihe and Reich (1993). So we see at least two different types of demand for entrepreneurship education; the push of broad social and economic imperatives and the more individualised pull by students seeking personal development and an adaptable skills base. Due to the nature of these demands it is 
unsurprising that academia is increasingly seeing entrepreneurship as a valuable discipline (Katz, 2003).

Entrepreneurship - content, context and educational expectations

However, it is very evident that these different constituencies of demand for enterprise education present very different, perhaps even incompatible, claims for what should be the outcome of this entrepreneurial education. If we examine the broad socio-economic demand, the emphasis here is placed on economic outcomes; new jobs; new businesses and innovation. Thus new high growth companies are the epitome of such demand, but such companies require high levels of industry and product knowledge, extensive organisational skills and an ability to acquire a strong capital base. Few of these qualities are possible to teach in any conventional educational scheme since most are experienced based. However, it is possible to learn about the nature of these qualities and to teach about how they can be acquired. Indeed the ability to engage students, entrepreneurs, business support professionals and learning facilitators is one of the advantages of entrepreneurship education (Collins et al, 2006). But if we look at the nature of students' requirements, we see a rather different picture. Entrepreneurship is unique in its capacity to combine an individual's skills and aspirations (Anderson, 2000). At the level of the individual entrepreneurship is seen as overcoming the barriers and obstacles of class, race and gender (Aldrich and Zimmer 1986; Stanworth and Curran 1973; Waldinger et al 1990; Hyrsky and Ali 1996). Entrepreneurship is also viewed as a means of satisfying an individual's "inner needs"; notions of satisfaction, fulfilment and achievement echo throughout the literature (Scott and Anderson 1994). Here the demand requirements can be characterised as awareness of entrepreneurial opportunity; understanding and enrichment of personal capability, but most likely to be manifest not in the establishment of high growth company, but most likely in a new small business. The needs of 
such new business are broadly managerial but coupled with vision and an appreciation of what is possible. These attitudes and abilities do seem to fit better with conventional pedagogies.

So, very different skills, abilities and knowledges may be required to fulfil these different entrepreneurial promises. We follow Gibb's point that the overriding aim of enterprise education is to develop enterprising behaviours, skills and attributes and by this means also enhance our student's insight into, as well as knowledge of, any particular phenomenon studied (Gibb, 1993). However it has been argued that there has been more faith than strategic reasoning in the development and implementation of enterprise and entrepreneurial education and training in the UK during the 1980s (Rosa, 1992). At one level we see new businesses, at another creative individuals who think for themselves. At yet another level, we note the need for more new high growth firms. As Hannon (2006:300) puts it, what is important and for whom, "Government, business, educationalists, parents and students may have different and conflicting conceptions of entrepreneurship education and what is valued and when and how".

The problem becomes even more complex when we examine the nature of entrepreneurship. Defining entrepreneurship has long been an issue, as Henry et al (2005) note, the literature abounds with theories and discussions about who or what is an entrepreneur. Indeed, after reviewing a number of types of definition, they seem to concur with Curran and Stanworth's (1989:12) account, "a new economic entity centred on a novel product or service or, at the very least, one which differs significantly from products offered elsewhere". For entrepreneurs, they cite Bruyat and Julien (2000), who see entrepreneurship as a process of change, emergence and the creation of new value. Smith et al (2006:557) on the other hand, 
provide a deceivingly simple definition, "entrepreneurs are people with entrepreneurial spirit". Yet paradoxically, we know that most new businesses are best described as small business rather than entrepreneurial. Consequently, the nature of entrepreneurship presents a formidable array of attitudes, skills and knowledge, experiences and ways of behaving that need to be taught. Hannon (2005;305) again summarises nicely, "the role of the entrepreneurial educator in HE is conceptually and pedagogically challenging". Johnson et al (2006:40) seem to agree, "pedagogically, entrepreneurship is still a conundrum for many". Unsurprisingly, Gorman et al (1997) comment, despite the considerable growth in entrepreneurship courses and programs there is very little consistency in approach.

This range of issues raises questions about what "entrepreneurship" comprises and how, and if, it can be taught within the conventional pedagogies. The demands outlined above appear to range from a science of business management to the necessarily imprecise notions of creativity; this art of entrepreneurship. Clearly entrepreneurship has to be different, or at least more than managerialism; there is something distinctive which reaches beyond the effective allocation of resources. Yet we must also recognise that successful business creation also demands managerial competencies. If we acknowledge that entrepreneurship is more than the basic and pragmatic skills to simply slot into a new business, the difference seems to lie in the novelty, the creation of new ventures, either as new businesses or as new ventures within existing organisations. We may characterise this as opportunity perception, developing these ideas into viable opportunities and pulling together resources to make these real. Nonetheless this creative process is not independent of managerial knowledge. Knowledge, and experience, is the basis for assessing what is possible, what is realistic and what is achievable. 
In trying to capture the essentials of enterprise, we propose that these different elements of the entrepreneurial endeavour can be presented in a typology of vocational roles. Figure 1 shows what we see as the different vocational categories, each of which features in entrepreneurship.

\section{Insert Figure 1 About Here}

These typologies provide us with some guidance about what we have to teach and may offer some indications of how we might best impart the skills, knowledge and attitudes necessary to be entrepreneurial. At the very least the typologies suggest that there is more to entrepreneurship than merely managing; at best they illustrate the style, range, scope and applications that are called for in entrepreneurship.

The highest level, the professional deals with the application of knowledge and judgement. It clearly calls for, as all professions do, a high level of specialised knowledge about entrepreneurship. In many ways this is the most problematic, if, for no other reason, than some 30 years of research have failed to identify precisely what this knowledge might comprise. However, we do know that some elements such as opportunity evaluation and the strategies necessary to realise that opportunity are core. So theoretical knowledge about entrepreneurship is critical here and an ability to employ that knowledge in analysis is essential. Interestingly, when we reflect on the generalised professional role, we note that few professionals do things themselves. Architects rarely build houses, few accountants run companies but many medical doctors not only advise but also carry out functional work. Intriguingly many medical schools have adopted a new pedagogic style, they teach by setting problems and asking students to solve the problem. Consequently we see the type of 
knowledge needed for professional work as largely theoretical and the ability to apply this abstracted knowledge to practical contexts. Thus we need to be able to teach "about" entrepreneurship and help students to develop the ability to use that knowledge.

The technician's role is more hands on than professional and focuses on knowing what rather than why. It represents the informed use of practical skills. Accordingly the technician's function is the skilled application of knowledge. We see this played out as a more managerial function of entrepreneurship; technicians need to know what has to be done and how to do it. Thus understanding theory still plays a part, but is less important than an informed ability to shape the business. Consequently we see the repertoire of things to be learned to include the functions of managing. For new business this may focus on the activities surrounding new venture planning, implementing strategies and coordinating the disparate elements that make a new business work.

The artisanal role concentrates on getting things done. The knowledge needed is entirely practical, knowing "how", so that skills are the vital element. This then is application of knowledge and requires us to teach how to do things such as the practical skills of marketing, accounting and similar practices. Here we see learning by doing as the most practical way of imparting these skills.

The artist's role is the creative dynamic. To borrow Baudelaire's (1981:435) formulation, the artist is someone who can concentrate his vision on ordinary subjects, understand there fleeting qualities, and yet extract from the passing moment. Or as Harvey quotes Bradbury and McFarlane (1976:27), "it is the one art that responds to the scenario of our chaos." Harvey again (1989:22), "The struggle to produce a work of art, a once and for all creation 
that could find a unique place in the market, had to be an individual effort forged under competitive circumstances." Ronstadt (1990) raises the issue of American higher education in the liberal arts and claims that rather than promoting an entrepreneurial perspective, business is marginalised. But Ray (1990:80) claims that, "an education in the liberal arts may be viewed as a metaphor for entrepreneurship. The humanities suggest that the entrepreneur is an artist". So for this role we need to be able to empower our students' imaginations, allow them to envisage opportunities in such ways that ideas can become opportunities. For this we need to develop cognitive skills, where they can learn how to apply fertile imagination to the real world. Again experience is the best teacher, but in its absence a critical ability based on surrogate experience may work.

Can we teach entrepreneurship and how best can we teach it?

Jerry Katz' seminal article (1991) makes the point that there are, most likely, entrepreneurial skills which can be taught and some that cannot. There is also preliminary evidence that entrepreneurial attributes can be positively influenced by educational programs and that many entrepreneurship programs and courses are able to build awareness of entrepreneurship as a career option and to encourage favourable attitudes toward entrepreneurship. So, in broad terms we seem to be able to teach some aspects of entrepreneurship. For example, starting and managing a new small business has much in common with the general principles of management. Management, or the functions of managing a small business, is now well established in academe. In the "ideal typification" teaching involves explaining the functions of management, the presentation of techniques and models of good practice, and evaluating student's ability to apply this knowledge to a historic or a make-believe situation. Mintzberg (1994), for example considers that in many MBA programmes the emphasis is on teaching 
about concepts and the administration of functional areas. French and Grey (1996), whilst acknowledging changes, note that the idea of management education as functional to management is predicated on a model of professional training in which there exists a body of knowledge which is understood to be central to effective practice. Locke (1993:31) however argues that the classic American Management was based upon what can be interpreted as Taylorist principles of Scientific Management. As George (1968) claims, Taylor's principles of scientific management were about standardisation, finding the one best way. Casson (1995:83) puts this uncompromising view into an entrepreneurial perspective, "But it is the perception, as well as the reality of problems which is important. Shackle, (1979) makes a similar point about the subjectivity of problems and the limitations of a narrow view. Thus it appears that we can teach "management" but may have some problems with entrepreneurial management. Ronstadt (1990:80) claims, "Entrepreneurship education should not be viewed as some mechanistic or technocratic process but as a holistic and integrative process". Later he notes (1990:92) that entrepreneurship is not the sum of the functional subdivisions of modern business education.

So it seems that, in broad terms, typical business school methods may be good at teaching formalised management methods, but less well equipped to deal with the "entrepreneurial" aspects. Laurenco and Jones (2006) point to a substantial body of literature which is critical of the adoption of traditional business and management pedagogical approaches Indeed, Solomon and Fernald (1991) point out that in the USA, the business courses of many colleges and universities were criticised because of their lack of creativity and individual thinking. Yet as Johannisson (1992) notes entrepreneurship is anti-positivistic and that entrepreneurial knowledge may be soft and personal. Thus we see the limitations of management education in dealing with the unknowability of entrepreneurship. As Casson (1995:80) puts it, 
"Judgmental decisions are decisions for which no obvious correct procedure exists: a judgmental decision cannot be made simply by plugging available numbers into a specific formula and acting on the basis of the number which comes out". Yet as Chia (1996) points out, the cultivation of entrepreneurial imagination is the single most important contribution of Universities and Business Schools.

Theory may be one solution to developing this entrepreneurial imagination. Theory is an abstracted form of knowledge which may be applicable in a range of circumstances- even circumstances which are as yet unknown- the very context of innovative enterprise. Moreover, a substantial body of entrepreneurial theory has been developed, and universities are well experienced at passing on theoretical knowledge. Fiet (1998) argues that we should teach students theory to support their practical learning experience. We need to provide a conceptual background which allows students to understand and to engage with the real business world. Fiet proposes that if we are to improve the substance of what we teach to students studying entrepreneurship, we need to 1) pursue theory-driven research agendas and be actively seen to do so and 2) expose students to theoretical explanations of why some entrepreneurs succeed and others fail. Fiet (1998) claims we become irrelevant as teachers, when we fail to apply theory as a tool to answer student questions. But Laurenco and Jones (2006) point to critiques of the tendency to over-emphasise theory and conceptual thinking, using teacher-centred learning styles and treating functional knowledge as an 'end' rather than a 'means'. Rae (2004) provides an interesting alternative, what he calls practical theory; practical theory emerges from the implicit, intuitive, tacit and situated resource of practice. 
Gibb (1996:311) makes the telling point that few business schools are in a strong position to meet the challenges of teaching an entrepreneurial holistic management approach. The conventional role of universities is to provide a theoretical understanding, a conceptual grasp of the phenomena, but we must also question the relevance and value of an overtly theoretical approach to a subject which appears to deal almost exclusively with doing. Furthermore, the lack of business experience in academe, which is typical of management lecturers (Simon 1976, Macfarlane, 1998) may exacerbate the situation. This is particularly so when in combination with the lacunae of students' own experience. This might lead to over reliance on theory, when what may be needed is practice. Young (1997) usefully defines entrepreneurial education as the structured formal conveyance of entrepreneurial knowledge. Entrepreneurial knowledge is the concepts, skill and mentality individual business owners use. Our point is that it may not be possible to acquire the skill, or indeed the mentality, by conventional pedagogic routes since this is normally experiential.

The picture that emerges is that we do need a theoretical underpinning to our entrepreneurial teaching. Theory provides an overview which is not limited to the particularities of one set of circumstances. Theory tells us about entrepreneurship in general terms that can be applied to knowing how. But knowing how is also important because it links into the realities of the experienced world. Yet as we have noted, many of the teachers and most of our students have limited real life experience in enterprising. Laurenco and Jones (2006:9) summarise the pedagogic problem rather well, "The first paradigm used the 'traditional mode' and the second uses the 'enterprise mode' in teaching entrepreneurship. As described previously, the 'traditional' mode to teaching entrepreneurship is theoretically focused and knowledge is passed on to learners. In contrast, the 'enterprise mode' emphasises the use of 'action learning' where knowledge is constructed by learners through the process of 'doing"'. 
Turning to consider the role typologies we identified, what our discussion highlights is the need to recognise and realise the need for both a theoretical and practical input in teaching entrepreneurship. However, we also emphasise the need to avoid an over reliance on theory rather than practice and instead appreciate the importance of integrating both aspects in curricula. In Figure 2 we present the role typologies and some examples of pedagogies in entrepreneurship that address some of the issues we have raised. We then turn to consider each role.

\section{Insert Figure 2 About Here}

If the aim of the professional role is to build theoretical knowledge but also analytical skills then as entrepreneurship educators we need to develop students who are able and capable of developing and discussing theoretical material and presenting conceptual and abstract ideas. But, perhaps more importantly, there is a need to provide the platforms and forums which allow our students to question, debate and contrast views, thoughts and perspectives. This will allow students to develop a grounded theoretical understanding. The development of analytical skills can be achieved through problem solving tasks. This might entail, for example, analysing case study material to identify the types of decisions potential and actual entrepreneurs take and the reasoning behind their actions, but also critiquing information to identify alternative ways of doing things. Other ways in which analytical skills might be developed are through assessing the business plans of others and looking at how and why a business might be structured in a particular way. 
We also need to encourage students to not only listen to classroom speakers but provide them with the confidence and ability to constructively question the decisions, skills and judgement of those speakers. The role of the technician involves the actual application of knowledge. This might be achieved through the design, development and preparation of a business plan, the "normal" venture planning tool, or role and enterprise simulation "games". Such tools can also be a useful way of developing individual and group thinking skills. However, there also has to be some mechanism that allows students to become reflective thinkers and to reflect on their own skills, participation and judgement about the processes involved. Mechanisms for achieving this are reflective essays and diaries. These can help with the learning process but also monitor the process in which students are immersed.

The artisanal role requires the application of skills. This might be achieved through work placements and apprenticeships, both short-term and long-term. However, mentoring, shadowing and buddy schemes alongside organisational visits, might also be used to consider the application of skills and how people make judgements and decisions. These skills are normally experientially acquired so we need to have in place some substitutes for this experience. Obviously this is difficult to do in the university environment, but remains essential for a successful new venture. Finally, there is the role of the artist which requires creativity and perception. This might be achieved through the task of generating and pursuing business ideas but also through developing the communication and presentation skills that allow students to present their business concepts and justify the suitability of their ideas to other individuals, ideally peers, business people and actual entrepreneurs. While the business plan offers one way to fulfil this requirement, other tools, such as posters, can also be particularly useful allowing students to be more creative but also more thoughtful about how they present their ideas. We need to have workshops where free thinking is encouraged; 
where ideas can be bounced around in a non-judgemental environment. We can use examples from cases, ideally live ones who talk to the students and are prepared to explain how their ideas emerged. The typologies and pedagogy perspectives proposed also highlights the need for more published research in the different fields to be made easily accessible to students.

\section{Conclusion}

We recognise that whilst the role of the professional, technician, artisan or artist might in some contexts be discrete and individual, it is the combination of roles that helps to develop the required skills for entrepreneurship. We appreciate that some entrepreneurial skills can be taught and that others cannot. Moreover, we also see a need to recognise that some people might become entrepreneurs whilst others might not. Our review highlights that universities may be good at teaching about the higher level skills, abilities and competencies, but we are less well able to teach the practical aspects. We must use surrogates for experience, find more ways of transmitting the thrill of new venture creation as well as forging the essentials of a grounded business acumen.

As university educators our role is not necessarily to create entrepreneurs, but to make individuals aware of what entrepreneurship might entail and the issues entrepreneurs face and equip them with the knowledge to deal with these issues. This is important when you consider that most of our students are likely to be employed in an entrepreneurial organization at some point in their career. According to Collins et al (2006) entrepreneurs are action oriented; they learn by doing, trial and error, problem solving and discovery (Deakins and Freel, 1998; Young and Sexton, 1997). Through posing the question what do we teach and how can we teach it, we have hopefully demonstrated that to be entrepreneurial requires individuals to be professionals, technicians, artisans and artists. Ideally, we should be 
attempting to create individuals who can and are able to be decisive, think for themselves but also through collaboration and/or the involvement with and of others. However, ultimately this also means that the teaching of entrepreneurship requires a combination of theory and practice. It is the ability to deliver the range of skills that meet both requirements that differentiates universities from the rest of the providers.

\section{References:}

Adcroft, A., Dhaliwal, S., Willis, R., 2005, Insatiable demand or academic supply: the intellectual context of entrepreneurship education, European Business Review, 17(6) 518531

Aldrich, H., Zimmer, C., 1986, Entrepreneurship through social networks. In D. Sexton and R. Smilor (Eds.), The Art and Science of Entrepreneurship. Ballinger Publishing Co., New York.

Anderson, A.R., 2000, The Protean Entrepreneur: the entrepreneurial process as fitting self and circumstance", Journal of Enterprising Culture, 8 (3) 201-234

Anderson, A.R., Jack, S., 1999, Teaching the Entrepreneurial Art. In D.S. Evans (Ed.) International Dimensions of Teaching Entrepreneurship, Ecole Supérieure de Commerce Et de Management (ESCEM), Lyon (http://www.escead.fr/idte/art.htm)

Bandura 1986 Social Foundation of Thought and Action, Prentice-Hall, Englewood Cliffs, NJ.

Baudelaire., C., 1981, Selected writings on Art and Artists, London

Bradbury, M., McFarlane, J., 1976, “Modernism, 1890-1930”, Penguin, Harmondsworth

Bruyat, C., Julien, P.A., 2000, Defining the field in entrepreneurship, Journal of Business Venturing, 16(2) 165-180

Casson M., 1995, Entrepreneurship and Business Culture: Studies in the Economics of Trust. Vol 1. Edward Elgar, Aldershot 
Chia, R., 1996, Teaching paradigm shifting in management education: University business schools and the entrepreneurial imagination, Journal of Management Studies, 33(4) 409428

Collins, L.A., Smith, A.J., Hannon, P., 2006, Applying a synergistic approach in entrepreneurship education, Management Learning, 37(3) 335-354

Cooper, S., Bottomley, C., Gordon, J., 2004, Stepping out of the classroom and up the ladder of learning; an experiential learning approach to entrepreneurship education, Industry and Higher Education, 18(1) 11-22

Curran J., 1986, Bolton 15 years on: A Review and Analysis of Small Business Research in Britain 1971-1986, Small Business Research Trust, London

Curran, J., Stanworth, J., 1989, Education and training for enterprise: some problems of classification, evaluation, policy and research, International Small Business Journal, 7(2) $11-23$

Deakins, D., Freel, M., 1998, Entrepreneurial learning and the growth process in SMEs”, The Learning Organisation, 5(3) 144-155

Delmar, F., Shane, S., 2004, Legitimating first: Organizing activities and the survival of new ventures, Journal of Business Venturing, 19, 385-410

Fiet, J.O. 1998, Education for Entrepreneurial Competence: A Theory-Based Activity Approach

Finkle, T.A., Deeds, D. 2001, Trends in the market for entrepreneurship faculty, 1989-1998, Journal of Business Venturing, 16(6) 613-630

Freel, M.S., 1989, Policy, prediction and growth: Picking winners?, Journal of Small Business and Enterprise Development, 5(1) 19-32

French, R., Grey, C., 1996, Rethinking Management Education, Sage Publications, London.

Galloway, L., Anderson, M., Brown, W., Wilson, L., 2005, Enterprise skills for the economy, 
Education and Training, 47(1) 7-17

Gallup Organisation And National Center For Research In Economic Education, 1994, Entrepreneurship and Small business in the United States: A Survey Report on the Views of the General Public, High School Students, and Small Business Owners and Managers, Kansas City, MO

Gartner WB, Shane SA., 1995, Measuring entrepreneurship over time, Journal of Business Venturing, 10(4) 283-301.

George C.S., 1968, The history of management thought, Prentice Hall Englewood Cliffs, N.J.

Gibb A.A., 1996, Entrepreneurship and small business management: Can we afford to neglect them in the Twenty-first century Business School, British Academy of Management Journal, 7(4) 309-321

Gibb, A.A. (1993), “The enterprise culture and education”, International Small Business Journal, Vol. 11 No.3, pp. 11-34

Gorman, G., Hanlon, D., King, W., 1997, Some research perspectives on entrepreneurship education, enterprise education and education for small business management: A ten-year literature review, International Small Business Journal, 15(3) 56-78

Gosling, J., 1996, Plato on the education of managers, in French, R., Grey, C. (Eds), Rethinking Management Education, Sage Publications, London.

Hannon, P. D., 2006, Teaching pigeons to dance: sense and meaning in entrepreneurship education, Education and Training, 48(5) 296-308

Hannon, P.D., 2005, Philosophies of enterprise and entrepreneurship education and challenges for higher education in the UK, International Journal of Entrepreneurship and Innovation, 6(2) $105-114$

Harvey, D., 1989, The Condition of Post-modernity, Basil Blackwell, Oxford

Heinonen, J., Poikkijoki, S-A., 2006, An entrepreneurial-directed approach to 
entrepreneurship education: mission impossible? Journal of Management Development, 25 (1) $80-94$

Henry, C., Hill, F., Leitch, C., 2005, Entrepreneurship education and training; Can entrerpeneurship be taught? Part 1, Education and Training, 47(2) 98-111

Hynes, B., 1996, Entrepreneurship education and training - introducing entrepreneurship into non-business disciplines, Journal of European Industrial Training, 20(8) 10-18

Hyrsky, K., Ali, A.A., 1996, The Rocky Road of Immigrant and Ethnic Business in Finland. Paper presented at the 2nd Irish Entrepreneurship Conference, Belfast, November.

Johannison, B., 1992, In Search of a Methodology for Entrepreneurship research, unpublished draft circulated at RENT VII, November.

Johnson, D., Justin, C.B.L., Hildebrand, 2006, Entrepreneurship education; towards a discipline based framework, Journal of Management Development , 25(1) 40-54

Jones, C., English, J., 2004, A contemporary approach to entrepreneurship education, Education and Training, 46(8/9) 416-423

Katz J., 1991, The institution and infrastructure of entrepreneurship, Entrepreneurship Theory and Practice, Spring 85-102

Katz, J.A., 2003, Chronology and intellectual trajectory of American entrepreneurship education 1876-1999, Journal of Business Venturing, 18(2) 283-300

Kirby, D., 2003, Entrepreneurship, McGraw Hill, London

Locke R.R., 1993, Higher education and management: their relational changes in the 20th century", in N. Kawabe and N. Daito (Eds.) Education and Training in the Development of Modern Corporations, University of Tokyo Press, Tokyo

Lourenco, F., Jones, O., 2006, Learning paradigms in entrepreneurship education: comparing the traditional and enterprise modes, working paper, accessed 18.01.07

http://www.newentrepreneurscholarships.org/download.php?file=media_room/news/nes_mmu 
report2006.pdf

Macfarlane B., 1998, Refugees, nomads and tourists: an anatomy of business and management lecturers in Higher Education, Journal of European Business Education, 7(2) 37-44

Matlay, H., 2001, Strategic issues in vocational education and training in central and Eastern Europe, Education and Training, 43(8/9) 395-404

Matley, H., 2006, Researching entrepreneurship and education Part 2: what is entrepreneurship education and does it matter? Education and Training, 48(8/9) 704-718

Mintzberg H., 1994, Re-engineering the Business School in M.L. International Newsletter, 1, June, p 24-25

Rae, D., 2004, Practical theories from entrepreneurs' stories: discursive approaches to entrepreneurial learning, Journal of Small Business and Enterprise Development, 11(2), 195202

Ray, D., 1990, Liberal arts for entrepreneurs, Entrepreneurship Theory and Practice, 15( 2), $79-93$

Ronstadt R., 1990, Contributing Editor's Feature, Entrepreneurship Theory and Practice, 15(2) 78-79

Rosa, P., 1992, Entrepreneurial Training in the UK: Past Confusion and Future Promise, Conference Paper Series 81/92, University of Stirling, Stirling

Scott, M.G., Anderson, A.R., 1994, Entreprenology: The Study of the Creation and Extraction of Value from an Environment, A paper presented at the 14th Babson Entrepreneurial Conference at Wellesley MA

Shackle G.S.L., 1979 Imagination and the Nature of Choice, Edinburgh University Press Edinburgh

Simon H.A., 1976, Administrative Behaviour, Collier-Macmillan, New York

Smith, A.J., Collins, L.A., Hannon, P.D., 2006, Embedding new entrepreneurship programmes 
in UK higher education institutions, challenges and considerations, Education and Training, 48(89), 555-567

Solomon G.T. Fernald W., 1991, Trends in small business management and entrepreneurship education in the United States, Entrepreneurship Theory and Practice, Spring 25-39

Stanworth, J., Curran, J., 1973, Management motivation in the smaller business, London, Gower Press.

Tan, W.L., Tan, L.K., Tan, W.H., Wong, S.C., 1995, Entrepreneurial spirit amongst tertiary students in Singapore”, Journal of Enterprise Culture, 3(2) 211-227

Timmons, J.A., 1994, New Venture Creation, Fourth Edition Irwin, Illinois

Vesper, K.H., McMullan, W.E., Ray, D.M., 1989, Entrepreneurship education: more than just an adjustment to management education, International Small Business Journal, 8(1) 61-65

Waldinger, R., Aldrich, H., Ward, R., 1990, (eds.), Ethnic Entrepreneurship: Immigrant Business in Industrial Societies. London, Sage Publications

Warren, D., 1980, Imperialism: Pioneer of Capitalism, New Left Books, London

Weihe H.J., Reiche F., 1993, reprinted 1997, Entrepreneurship interest among business students: Results of an international survey. In H. Klandt (ed) Entrepreneurship and Business Development, Avebury, Hants.

Young J.E., 1997, Entrepreneurship education and learning for university students and practising entrepreneurs. In D. Sexton and R.W. Smilor (Eds.) Entrepreneurship 2000, Upstart Publishing, Chicago

Young, J.E., Sexton, D.L., 1997, Entrepreneurial learning: a conceptual framework, Journal of Enterprising Culture, 5(3) 223-248 
Figure 1: Role typologies in entrepreneurship

\begin{tabular}{|c|c|c|c|c|}
\hline Role & Task & Knowledge & Ability & Action \\
\hline Professional & $\begin{array}{l}\text { Analysis and application } \\
\text { of judgement to an } \\
\text { informed knowledge base }\end{array}$ & $\begin{array}{l}\text { Know how } \\
\text { and know why }\end{array}$ & $\begin{array}{l}\text { High level of theory } \\
\text { knowledge, analytical } \\
\text { skills }\end{array}$ & $\begin{array}{l}\text { Hands } \\
\text { off }\end{array}$ \\
\hline Technician & $\begin{array}{l}\text { Skilled application of } \\
\text { knowledge }\end{array}$ & $\begin{array}{l}\text { Know how } \\
\text { and know } \\
\text { what }\end{array}$ & Applied knowledge & $\begin{array}{l}\text { More } \\
\text { hands } \\
\text { on }\end{array}$ \\
\hline Artisan & $\begin{array}{l}\text { Skills and task } \\
\text { involvement }\end{array}$ & $\begin{array}{l}\text { Practical, } \\
\text { know how }\end{array}$ & Application of skills & $\begin{array}{l}\text { Hands } \\
\text { on }\end{array}$ \\
\hline Artist & Creativity and perception & $\begin{array}{l}\text { Knowing and } \\
\text { showing }\end{array}$ & $\begin{array}{l}\text { Ability to transpose } \\
\text { and transfer from } \\
\text { different mediums, }\end{array}$ & $\begin{array}{l}\text { Hands } \\
\text { on }\end{array}$ \\
\hline
\end{tabular}


Figure 2: Role typologies and pedagogies in entrepreneurship

\begin{tabular}{|c|c|c|}
\hline Role & Task & Examples of applicable pedagogical techniques \\
\hline Professional & $\begin{array}{l}\text { Stage One: Building } \\
\text { theoretical knowledge }\end{array}$ & $\begin{array}{l}\text { Developing and discussing theoretical, abstract } \\
\text { and conceptual knowledge and understanding } \\
\text { about entrepreneurship from previous, current } \\
\text { and ongoing research debates and perspectives } \\
\text {-lectures and texts } \\
\text { Developing analytical skills through problem } \\
\text { solving tasks, for instance using and analysing } \\
\text { case study material, business plans, listening to } \\
\text { and questioning the motivations and decisions of } \\
\text { entrepreneurs } \\
\text {-case studies, guest lecturers }\end{array}$ \\
\hline Technician & Applied knowledge & $\begin{array}{l}\text { Actual design and development of business plans, } \\
\text { reflecting on own skills and judgements, } \\
\text { gathering of information from variety of sources } \\
\text { and evaluating it, individual thinking skills, group } \\
\text { thinking skills } \\
\text { - case studies, examples and business planning } \\
\text { exercises }\end{array}$ \\
\hline Artisan & Application of skills & $\begin{array}{l}\text { Mentoring/shadowing/buddy schemes, work } \\
\text { placements, temporary apprenticeships, }\end{array}$ \\
\hline
\end{tabular}




\begin{tabular}{|c|c|c|}
\hline & & $\begin{array}{l}\text { organisational visits, development of networks } \\
\text {-learning by doing, field work; } \\
\text { technical/functional skills acquired by active } \\
\text { learning from texts and examples }\end{array}$ \\
\hline Artist & Creativity and perception & $\begin{array}{l}\text { Generating business ideas, communication and } \\
\text { presenting business concepts and material to } \\
\text { other individuals (through use of business plan, } \\
\text { poster, etc.) } \\
\text { - free thinking and thinking by association, } \\
\text { workshops, examples }\end{array}$ \\
\hline
\end{tabular}

